\title{
The Effect of Designing a Blended Learning Environment on Achievement and Deep Learning of Graduate Students at the Arabian Gulf University
}

\author{
Ahmed Nouby*, Tayseer Alkhazali \\ Distance Learning Department, College of Graduate Studies, Arabian Gulf University, Manama, Kingdom of Bahrain \\ Email: *ahmedmns@agu.edu.bh, taysirmna@agu.edu.bh
}

How to cite this paper: Nouby, A. and Alkhazali, T. (2017) The Effect of Designing a Blended Learning Environment on Achievement and Deep Learning of Graduate Students at the Arabian Gulf University. Open Journal of Social Sciences, 5, 248-260. https://doi.org/10.4236/jss.2017.510022

Received: September 3, 2017

Accepted: October 28, 2017

Published: October 31, 2017

Copyright $\odot 2017$ by authors and Scientific Research Publishing Inc. This work is licensed under the Creative Commons Attribution International License (CC BY 4.0).

http://creativecommons.org/licenses/by/4.0/

\begin{abstract}
The present study aimed to investigate the effect of designing a blended learning environment on achievement and deep learning of the Arabian Gulf university students in a design and presentation of instructional materials' graduate course. A blended learning environment was designed to provide opportunity for integrating the learning management system "moodle" with face-to-face classroom interaction. To investigate research questions, a quasi experimental design was used. The study sample consisted of 19 male and female graduate students pursuing their studies at the "Distance Teaching and Training Program" in the College of Graduate Studies during the first semester of the academic year 2015/2016. To explore the extent to which students learnt the course content, an achievement test was used. A deep learning scale was also used to investigate the depth of learning acquired by students who studied the course content through the blended learning environment. Results of the study showed that students' scores on the post application of the achievement test were improved. No statistically significant differences were found between students' mean scores in the pre and post applications of the depth of learning scale. However, mean of students' scores in the post application of the depth of learning scale (65.3750) was noticed to be slightly higher than that of the pre application (63.1250). Such higher mean might represent slight improvement in the depth of learning among students.
\end{abstract}

\section{Keywords}

Blended Learning Environment, Achievement, Deep Learning, Arabian Gulf University 


\section{Introduction}

Recent technological breakthroughs have led to improvements in almost all educational practices. Such improvements helped teachers educators to develop their pedagogical practices, which in turn impacted performance of learners whose cognitive and/or knowledge acquisition has increased widely because of integrating advanced e-learning technologies in instruction. Learning via electronic media has become an integral part of formal educational systems in educational institutions including universities, in particular [1] [2] [3]. Further developments in pedagogical practices have led to emergence of the concept of "blended learning" which mixes traditional learning and electronic learning. Blended learning has emerged as a natural growth of e-learning. It (blended learning) came as an attempt to overcome weaknesses of both traditional and electronic forms of learning. Blended learning as an approach to learning has gained momentum because of its widespread integration in educational organizations and training centers [4] [5]. Utilization of blended learning (mixed learning) has proven to enhance and increase the effectiveness and efficiency of teaching and learning in both instructional and training environments [6] [7] asserted that modification of instructional practices takes place by mixing traditional learning with internet based learning which in turn leads students to: Focus on desired instructional skills such as critical thinking, carry out their responsibilities in the process of learning, and organize the process of learning resource utilization. Moreover, mixing traditional and electronic forms of learning (i.e., blended learning) provides learners with electronic instructional resources viewed to be lacking in traditional learning environments. As such, it became extremely important to transform traditional learning environment into blended learning environment where traditional face-to-face classroom engagements are mixed with e-learning activities. Such a state of affairs contributed in many ways to improvements in learners' achievement of a wide variety of learning outcomes including learning of concepts and deep learning that will be investigated in this research paper.

\section{Blended Learning}

Recently, it has been repeatedly argued that the term "blended learning" has become a corporate buzzword [8] [9]. No clear single definition is available, and no clear common understanding of what blended learning is all about is available either [10] [11] [12] [13]. In general, blended learning related literature usually addresses five critical questions and/or issues that are still not clearly agreed upon by prominent researchers in the field. Such issues include: Definition of the term blended learning; reasons for that currently exist; difficulties and challenges encountered by instructors and trainers when blending; and future directions and trends of blended learning systems [8] [10] [14]. What is clearly agreed upon among a great many researchers is the following points of departure: Blended learning is a big educational thing that is replacing e-learning; blended 
learning is a new innovative way which combines face-to-face residential learning and computer mediated learning; and the potential that blended learning could become the only way of learning in the future. As a newly developed learning approach that embraces the traditional values of face-to-face teaching and integrates the best practices of computer mediated learning activities. In blended learning, electronic learning tools utilize lectures, lessons, and training sessions that usually take place in regular classrooms connected to internet communication. In this context, [15] states that blended learning is a mix of traditional face-to-face learning and e-learning activities including choices related to the way content is learnt, different communication tools between teacher and his/her students, between students themselves, and between students and instructional content to be learnt. [16] views blended learning as an integration of electronic instructional media and traditional teaching methods. Various delivery modes of instructional materials including a mix of direct lecturing, online communication, self learning activities, electronic performance support system, and learning management systems are utilized in blended learning [17] [18]. In brief, it can be stated that main components of blended learning as a newly developed instructional approach include: Face-to-face regular classroom interactions between teachers and their students; traditional learning materials such as printed textbooks, workbooks, work sheets; computer based learning through e-learning environment, an electronic assessment and feedback. Most importantly, the learner in blended learning is the center of the learning process [19] [20].

\section{Why Blending?}

As strong advocates of blended learning environments, [20] and [5] described such environments as ones that allow users to have the "best of both worlds" if they are well designed. Beyond this very general statement, research cited in the blended learning literature suggested three main reasons for adopting blended learning approach over other learning options: 1) effective pedagogical practices, 2) increased convenience and access to knowledge, and 3) greater cost effectiveness [8]. Only as examples of such reasons, proponents of blended learning environments mentioned the following benefits for blended learning:

- increase in the level of active learning strategies used [19] [20] the learner rather than the teacher becomes the center of the learning process [20] [21];

- peer-to-peer learning gets greater emphasis [19];

- flexibility in meeting individual differences and learning styles increased mentoring of individual learners [22] [23];

- the possibility of social interaction and easy communication with distant experts, mentors, professionals, or peers [24];

- increased access and convenience to instructional materials [12] [19] [20];

- reducing learning costs compared to other learning systems [6] [12];

- using instructional technology tools and applications in the process of design, implementation and utilization of instructional materials [11] [13] [25]; and 
- Disseminating of knowledge through internet which eliminates information technology literacy [8] [25].

Within the context of blended learning benefits, it was argued by Voci \& Young [22] that blended learning takes into account variation in learning styles of students and allows them to learn at their own pace according to their individual abilities. Blended learning enables learners to learn independently and be in control of the learning process coupled with facilitating cooperative learning as well as using advanced instructional technologies [21], who in their study found that academic achievement of students, taught through blended learning was very much better than that of students totally taught on the internet or taught in traditional classrooms. Results of their study also revealed that many students expressed dissatisfaction with learning totally on the internet as they miss face-to-face interaction provided in blended learning. Also in this context, Noirid \& Srisa-ard [26] asserted that blended learning had the potential to increase learners' comprehension and application of newly acquired skills. Similarly, results of a great many studies asserted that blended learning has become a learning mode that is increasingly being adopted in educational and training environments as an effective strategy to improve learning and training outcomes compared to online learning alone [6] [20] [27] [28] [29].

Proponents of blended learning such as Collis [19]; Dziuban, Hartman, and Moskal [21]; Graham [8]; Harman \& Koohang [2]; and Krause, 2007 argued that in order that blended learning programs are implemented effectively, the following issues must be considered: maintaining good planning to integrate e-learning technology in a blended learning environment, and to identify function of every medium and how to accurately use it in the blended learning program by teachers and learners; making sure that learners and teachers have skills needed to utilize e-learning technology in blended learning environment; ensuring that equipment, references and different resources needed for blended learning are available; starting the blended learning program with an introducing session where teachers and learners get to meet face-to-face to explain objectives, strategies, and implementation procedures of the blended learning program; and ensuring that teachers are available to respond to learners' enquiries whether online or face-to-face.

\section{Deep Learning}

Higher education institutions including colleges and universities are doing their utmost efforts to provide their learners with the best and most rewarding educational experiences. Realizing that time is ripe to update the entirely lecture-based traditional pedagogical practices, many universities have begun to change their existing teaching-learning practices and strategies in order to enhance students' learning experiences. Adoption of deep learning strategies in colleges and universities is believed to be one factor that leads students' productive learning experiences [30]. In their design-based research study, Shearer [31], Gregg, and 
Joo (2015) explored the concept of deep learning through a series of design changes in a graduate education course in order to build upon learning activities that instructors expect to reflect deep levels of learning. Even though the classification of learning preferences into deep and surface learning was developed by Marton and Saljo [32] back in 1976, there is still no set definition of deep learning and surface learning as approaches to study. Biggs [32], Entwistle [33], and Ramsden [34] elaborated on the classification proposed by Mart on and Saljo [35] and mentioned a list of features that characterize deep learning as an approach to study: It (deep learning) is connected with intrinsic motivation; focuses on learning principles; relates new knowledge to previously learnt knowledge; relates students' theoretically acquired ideas to their everyday life practical situations or experiences; relates and distinguishes evidence and argument; organizes and structures content into coherent; connects parts of the subject matter to each other and to real world situations; students comprehend the world by re-interpreting acquired knowledge; students learn beyond the instructional goals of the specified courses; finally, and deep learning is perceived to be more intellectually challenging, exciting, and more satisfying.

\section{Research Questions}

1) What are the instructional design standards for designing a blended learning environment?

2) What is the effect of designing a blended learning environment on the Arabian Gulf University students' learning of concepts in a graduate course about the design and presentation of instructional materials?

3) What is the effect of designing a blended learning environment on the Arabian Gulf University students' deep learning in a graduate course about the design and presentation of instructional materials?

\section{Research Hypotheses}

1) Designing a blended learning environment has an effect on the Arabian Gulf University students' learning of concepts in a graduate course about the design and presentation of instructional materials.

2) Designing a blended learning environment has an effect on the Arabian Gulf University students' deep learning in a graduate course about the design and presentation of instructional materials.

\section{Research Aims}

The present study aimed to investigate the effect of designing a blended learning environment on the Arabian Gulf University students':

1) Learning of concepts in a graduate course about the design and presentation of instructional materials.

2) Deep learning in a graduate course about the design and presentation of instructional materials. 


\section{Significance of the Study}

Significance of this study stems from the fact that it represents a very modest attempt to design a blended learning environment according to a set of appropriately instructional design standards, and investigate the effect of its use on students' learning of concepts as well as deep learning in a graduate course. Furthermore, theoretical questions and/or issues addressed by authors of this preliminary study might be informative to those interested in knowing about "blended learning", why blending, and features of deep learners.

\section{Method and Procedures}

A blended learning environment was designed to provide opportunity for integrating the learning management system "moodle" with face-to-face classroom interaction. To investigate research questions, a quasi experimental design was used. The study sample consisted of 19 male and female graduate students from the Gulf Cooperative Council pursuing their studies at the "Distance Teaching and Training Program" in the College of Graduate Studies.

\section{Research Instruments}

Research instruments used in the study included:

1) A cognitive Achievement Test

Researchers constructed a cognitive achievement test to measure the extent to which students learnt concepts embodied in a graduate course about design and presentation of instructional materials. Such test was composed of six questions that represented two types of questions that were:

a) A (5) item short answer questions

b) A (10) item true or false question

To verify the test reliability, researchers used Cronbach's alpha to figure out the internal consistency coefficient of the test items. Value of the reliability coefficient of this instrument came to be (30.6).

2) Deep Learning Scale

The deep learning scale is composed of four dimensions that are very much related to each other [31]. The four dimensions of the scale are: Finding meanings, relating ideas, using evidences, and looking for new knowledge. The scale has 16 statements distributed equally between its four dimensions. Students are asked to report their responses on a five point Lickert scale. Table 1 shows the distribution of statements of the deep learning scale among the four dimensions.

Researchers used a deep learning scale translated into Arabic and made sure that each statement is related to the dimension it belongs to. Arabic translation of the scale was reviewed by a number of educationists majoring in curriculum and instruction, methods of teaching, and measurement and evaluation. Reviewers were asked to judge the scale's content validity, its Arabic translation, and proper wording and relevance of the statements for each dimension. Internal consistency reliability of the scale was ascertained through using alpha 
Table 1. Statements of the deep learning scale distribution among the four dimensions.

\begin{tabular}{|c|c|c|}
\hline Dimension & Meaning & $\begin{array}{c}\text { Statements Related to the } \\
\text { Dimension }\end{array}$ \\
\hline $\begin{array}{l}\text { Finding } \\
\text { meaning }\end{array}$ & $\begin{array}{l}\text { Trying to comprehend themes of the } \\
\text { instructional content }\end{array}$ & $1,5,2,13$ \\
\hline Relating ideas & $\begin{array}{l}\text { Relating ideas/knowledge learnt to other } \\
\text { information in the course }\end{array}$ & $3,6,10,14$ \\
\hline $\begin{array}{l}\text { Using } \\
\text { evidences }\end{array}$ & Relating evidences to conclusions & $9,7,11,15$ \\
\hline $\begin{array}{l}\text { Looking for } \\
\text { new ideas }\end{array}$ & $\begin{array}{l}\text { Getting interested in learning new } \\
\text { knowledge for the sake of knowledge itself }\end{array}$ & $4,8,12,16$ \\
\hline
\end{tabular}

Cronbach's coefficient. As the reliability value came to be (0.86), it was viewed to be acceptable and the scale was appropriate to be used in the study.

\section{Research Procedures}

The e-learning environment (moodle) was blended with the face-to-face classroom interaction to create a blended learning environment. The course on "Design and Presentation" of instructional materials was uploaded on "moodle", and each student enrolled in the course was provided with username and password to access the e-learning environment.

\subsection{Study System and the Teaching-Learning Methods Adopted by the Distance Teaching and Training Program}

Faculty members in charge of the distance teaching and training program adopt a flexible instructional strategy in which blended learning is employed in carrying out instructional activities as follows:

- Studying the courses (modules) required by admitted students to the master degree program in distance teaching and training starts the first week of the first semester of the academic year. Completion of instructional activities of each module takes four consecutive weeks. During the first week, students meet their instructor in a computer lab for 30 hours of extensive face-to-face meetings during which the instructor goes over the course syllabus; explains the course outlines, objectives, and instructional strategies and assessment. An introduction to the virtual learning environment (moodle) takes place during the first meeting of this week. Students are provided with a course book and other related printed materials to the module content. After presenting the main ideas of instructional topics included in the three units of the module, the instructor asks students to carry out learning activities individually, peer groups, or in small groups. Toward the completion of the learning activities, students present them in class and get feedback from class discussions.

- As the course (module) instructional materials are uploaded on the virtual learning environment (moodle), students can communicate with their instructors while working on their self learning activities and assignments dur- 
ing the second week. Furthermore, students can meet with their instructors face-to-face. To activate cooperative learning, instructors may place some related topics on the moodle and ask students to discuss them in small groups. E-blogs might be used by instructors in the program.

- During the third and fourth week of the course students free themselves to complete assignments required and submit them electronically on or before due dates.

\subsection{Design of the Experimental Treatment Materials}

The ASSURE instructional design model was used to develop materials of the experimental treatment. This model provides a systematic way to plan then develop lessons that effectively integrates the use of instructional media to help assure effective teaching learning practices. Furthermore, the ASSURE model is one of the instructional design models that can be used by teachers to develop instructional processes making use of whatever media, resources, facilities or support services are available in classrooms. Each letter of the six letter ASSURE acronym refers to a step in the instructional design process.

- Analyze Learners' Characteristics:

The first step in the ASSURE instructional design model is to analyze the general and specific characteristics of learners such as age, grade level, motivation level, interests, attitudes, preferred learning styles, and academic abilities. As such, analysis of characteristics of students representing the present study sample revealed that all 19 male and female students were enrolled in the diploma and master degree programs in distance teaching and training in the College of Graduate Studies. They come from the State of Kuwait and the Kingdom of Bahrain. All of them hold a BA or BSc degree in a recognized field of study. It soon became clear that students representing the sample of the study were intrinsically motivated and very much interested in pursuing their master and doctorate degrees in the field of distance teaching and training.

- Sate Objectives:

In this step of the ASSURE instructional design model standards and learning objectives of the module are stated. Instructional designer or teacher trainer must specify what the students or trainers will know or will be able to do as a result of learning or training. Learning objectives should be stated as specific as possible, and should be observable and measurable. And in the present research, designing of a blended learning environment aims to enhance students' interaction with the instructor and with each other for the purpose of achieving learning objectives of the module. Interaction with instructional resources and making use of whatever learning facilities available helps students to accomplish learning or training activities.

- Select Media and Materials:

In this step of ASSURE model adoption for planning and developing instructional lessons is to select instructional technologies, media and materials that are suitable to the learners or trainers and appropriate for the specified learning ob- 
jectives. In this piece of research a set of instructional materials and a variety of individual and group of teaching learning activities were designed. Examples of such instructional materials and activities available for students on the "moodle" included lectures, demonstrations, power point presentations, discussions, and individual, peer or cooperative group activities. Such instructional materials and activities were selected to help learners achieve stated objectives of the module.

- Utilize Media and Materials:

In this step of the ASSURE instructional design model the instructor or trainer plans to utilize selected media and materials effectively. A detailed strategy is developed by the instructor or trainer to clarify the following critical questions: How to use selected media and materials, how much time is needed to go over the materials, what kind of equipment is needed, what assessment tools or methods used, and what instructional sequence is appropriate for carrying out instruction? And in this study, the instructor identified the main topics of the module and explained their learning objectives, determined time needed to discuss each topic, demonstrated methods of presentation and assessment strategies of students' assignments. Students were added in the module that has been uploaded on the virtual learning environment "moodle". Students were also trained to access the module electronically in order to be able to practice blended learning.

- Require Learners' Responses:

In this step of the ASSURE model a description of how students will handle the information included in the designed instructional plan is provided by the instructor or trainer. The description shows how the instructor or trainer intends to make learners actively involved in the instructional activities. As active learning participation by students is critical for learning to take place, it is extremely important to emphasize role of the learner in constructing learning activities and practicing them. Activating the notion of the active learning in the present study, instructor of the module employed dialogue and discussion techniques to motivate students to actively participate in the learning process. In some cases students were asked to comment on viewpoints proposed by instructor of the module or by their classmates.

- Evaluate and Revise Lesson Plan:

Toward the end of offering instructional or training activities, it is extremely significant to conduct comprehensive evaluation of the learning process for the purpose of finding out whether or not the learning objectives are actualized. Elements of the learning process that should be evaluated may include presentations, instructional activities, media and equipment used, support services, and learners themselves. Such comprehensive evaluation seeks answers to questions like:

a) Did the students achieve learning objectives? If so, how well they mastered learning objectives?

b) Did the presentations and techniques used help learners or trainees accomplish learning requirements of the instructional module? Were the students or 
trainees satisfied with whatever knowledge or skills acquired?

c) Did the assessment strategies used match the stated learning objectives?

d) Can all learners or trainees use instructional materials properly?

e) Did the module activities carried out by students encourage them to get involved in blended learning? Did such activities affect students' attitudes toward learning on virtual learning environments?

Based upon answers to such questions, the instructor or trainer decides whether or not stated learning objectives are achieved, and revisions follow suit.

\section{Results of the Study}

Results Related to Students' Achievement:

Table 2 reveals the difference between the experimental group mean scores of the pre and post applications of the achievement test. The $t$ test value of $(0.000)$ proved to be statistically significant at $(a=0.05)$. The mean score of the experimental group post application of the achievement test was higher than that of the pre application. This higher value of the mean score may prove that designing a blended learning environment has a positive effect on students' achievement and/or learning of concepts addressed in the design and presentation module.

Results Related to Students' Deep Learning:

Table 3 reveals the difference between the experimental group mean scores of the pre and post applications of the deep learning scale. The $t$ test value of $(0.186)$ proved to be statistically insignificant at $(a=0.05)$. The mean score of the experimental group post application of the deep learning scale was slightly higher than that of the pre application. This slightly higher value of the mean score may indicate that designing a blended learning environment has a modest positive effect on deep learning of students enrolled in the design and presentation module.

Table 2. Test results of the significance level of the difference between the experimental group mean scores of the pre and post applications of the achievement test.

\begin{tabular}{cccccc}
\hline Experimental Group Test Results & Mean & SD & $(\mathrm{t})$ value & df & Significance Level \\
\hline Pre application of the achievement test & 6.1053 & 0.31530 & & & \\
Post application of the achievement test & 18.8947 & 2.53629 & & 18 & 0.000 \\
\hline
\end{tabular}

Table 3. (T) test results of the significant level of the difference between the experimental group mean scores of the pre and post applications of the deep learning scale.

\begin{tabular}{cccccc}
\hline Experimental Group Test Results & Mean & SD & $(\mathrm{t})$ value & df & Significance Level \\
\hline Pre application of the deep learning scale & 63.1250 & 8.46857 & & & \\
& & & 1.388 & 15 & 0.186 \\
Post application of the deep learning scale & 65.3750 & 7.30183 & & & \\
\hline
\end{tabular}




\section{Discussion of Results}

With respect to the first research hypothesis related to learning concepts introduced in the design and presentation module, results of statistical analysis revealed that a statistically significant difference existed between the experimental group mean scores of the pre and post applications of the achievement test. Such difference was in favor of the post application. The higher value of the mean scores may prove to a large extent that designing a blended learning environment has a positive effect on students' achievement and/or learning of concepts addressed in the design and presentation of the distance teaching and training module. Such positive effect might be interpreted in terms of the effectiveness of the blended learning approach adopted by the instructor to handle instructional activities of the module. Students got very actively involved in the learning processes and methods that varied between face-to-face meetings with instructor and e-learning in the virtual learning environment (moodle). It could be argued that the moodle learning environment enabled students to establish their own learning community where they get involved in discussions, electronic dialogues, and cooperative learning activities to accomplish their learning tasks and assignments of the module. As such, researchers could assert that those results support the first hypothesis of the study related to designing a blended learning environment and investigating its effect on students' learning of concepts presented in a graduate course. Furthermore, statistical analysis of results of students on the deep learning scale showed that no statistically significant difference existed between the experimental group mean scores of the pre and post applications of the deep learning scale. This result might be due to students' interest in learning theoretical parts of the module and their concentration on completing their assignments as quickly as possible as time available is very limited. Students did not have enough time to enact deep learning features in their learning of the module. Furthermore, students responded positively to the statements of the deep learning scale in both applications of the scale, as its statements were general and simple. Hence, there were no statistically significant differences in the pre and post applications of the scale. However, the mean score of the experimental group post application of the deep learning scale was slightly higher than that of the pre application. This slightly higher value of the mean score may indicate that designing a blended learning environment has a modest positive effect on deep learning of students enrolled in the design and presentation module.

\section{References}

[1] Delacey, B.J. and Leonard, D.A. (2002) Case Study on Technology and Distance in Eduction at the Harvard Business School. Educational Technology \& Society, 5.

[2] Harman, K. and Koohang, A. (2005) Discussion Board: A Learning Object. Interdisciplinary. Journal of Knowledge \& Learning Objects, 1, 67-77.

http://ijello.org/Volume1/v1p067-077Harman.pdf

[3] Mason, R. and Rennie, F. (2006) Elearning: The Key Concepts. Taylor \& Francis 
Group, New York.

[4] Rovai, A.P. and Jordan, M. (2004) Blended Learning and Sense of Community: A Comparative Analysis with Traditional and Fully Online Graduate Courses. The International Review of Research in Open and Distance Learning, 5.

http://www.irrodl.org/index.php/irrodl/article/view/192/274

https://doi.org/10.19173/irrodl.v5i2.192

[5] Young, J.R. (2002) "Hybrid" Teaching Seeks to End the Divide between Traditional and Online Instruction. Chronicle of Higher Education, A33.

[6] Bersin \& Associates (2003) Blended Learning: What Works?: An Industry Study of the Strategy, Implementation, and Impact of Blended Learning: Bersin \& Associates.

[7] Condie, R. and Livingston, K. (2007) Blending Online Learning with Traditional Approaches: Changing Practices. British Journal of Educational Technology, 38, 337-348. https://doi.org/10.1111/j.1467-8535.2006.00630.x

[8] Graham, C.R. (2006) Blended Learning Systems: Definition, Current Trends, and Future Directions. In: Bonk, C.J. and Graham, C.R., Eds., Handbook of Blended Learning: Global Perspectives, Local Designs, Pfeiffer Publishing, San Francisco, 3-21.

[9] Lamb, J. (2001) "Blended Learning” Is the New Buzz Phrase. https://www.ft.com/

[10] Garrison, R. and Kanuka, H. (2004) Blended Learning: Uncovering Its Transformative Potential in Higher Education. Internet and Higher Education, 7, 95-105. https://doi.org/10.1016/j.iheduc.2004.02.001

[11] Rossett, A. (2002) The ASTD E-Learning Handbook. McGraw-Hill.

[12] Singh, H. and Reed, C. (2001) Achieving Success with Blended Learning. Centra Software. ASTD State of the Industry Report. American Society for Training and Development.

[13] Thomson, I. (2002) Thomson Job Impact Study: The Next Generation of Corporate Learning. http://www.netg.com/DemosAndDownloads/Downloads/JobImpact.pdf

[14] Osguthorpe, R. and Graham, C. (2003) Blended Learning Environments Definitions and Directions. The Quarterly Review of Distance Education, 43, 227-448.

[15] Fransen, J. (2006) Een nieuwe werkdefinitie van blended learning. [A New Working Definition of Blended Learning.] Dutch Open University Journal Onderwijs Innovatie, 8, 26-29.

[16] Trapp, S. (2006) Blended Learning Concepts-A Short Overview. Innovative Approaches for Learning and Knowledge Sharing, EC-TEL Workshops Proceedings, 28-35.

[17] Kirkley, S.E. and Kirkley, J.R. (2005) Creating Next Generation Blended Learning Environments using Mixed Reality, Video Games and Simulations. TechTrends, 49, 42-53. https://doi.org/10.1007/BF02763646

[18] Kirkley, J.R. and Kirkley, S.E. (2006) Expanding the Boundaries of Blended Learning: Transforming Learning with Mixed and Virtual Reality Technologies. In: Bonk, C.J. and Graham, C.R., Eds., Handbook of Blended Learning: Global Perspectives, Local Designs, Pfeiffer Publishing, San Francisco, 533-549.

[19] Collis, B. (2003) Course Redesign for Blended Learning: Modern Optics for Technical Professionals. International Journal of Continuing Engineering Education and lifelong Learning, 13, 22-38. https://doi.org/10.1504/IJCEELL.2003.002151

[20] Morgan, K.R. (2002) Blended Learning: A Strategic Action Plan for a New Campus. 
University of Central Florida, Seminole.

[21] Dziuban, C.D., Hartman, J. and Moskal, P.D. (2004) Blended Learning. EdUCAUSE for Applied Research. Research Bulletin, 7.

[22] Voci, E. and Young, K. (2001) Blended Learning Working in a Leadership Development Programme. Industrial and Commercial Training, 33, 157-160. https://doi.org/10.1108/00197850110398927

[23] Waddoups, G. and Howell, S. (2002) Bringing Online Learning to Campus: The Hybridization of Teaching and Learning at Brigham Young University. International Review of Research in Open and Distance Learning, 2. https://doi.org/10.19173/irrodl.v2i2.52

[24] Levine, S.L. and Wake, W.K. (2000) Hybrid Teaching: Design Studios in Virtual Space. National Conference on Liberal Arts and the Education of Artists, New York.

[25] Driscoll, M. (2002) Blended Learning: Let's Get beyond the Hype. E-Learning, 54.

[26] Noirid, S. and Srisa-ard, B. (2007) E-Learning Models: A Review of Literature.

[27] Graham, C.R., Allen, S. and Ure, D. (2003) Blended Learning Environments: A Review of the Research Literature. Unpublished Manuscript, Provo, UT.

[28] Reay, J. (2001) Blended Learning-A Fusion for the Future. Knowledge Management Review, 4, 6.

[29] Rooney, J.E. (2003) Blended Learning Opportunities to Enhance Educational Programming and Meetings. Association Management, 55, 26-32.

[30] Floyd, K.S., Harrington, S.J. and Santiago, J. (2009) The Effect of Engagement and Perceived Course Value on Deep and Surface Learning Strategies. Informing Science: The International Journal of an Emerging Transdiscipline, 12, 181-190.

[31] Shearer, R.L., Gregg, A. and Joo, K.P. (2015) Deep Learning in Distance Education: Are We Achieving the Goal? American Journal of Education, 29, 126-134. https://doi.org/10.1080/08923647.2015.1023637

[32] Biggs, J.B. (1987) Student Approaches to Learning and Studying. Australian Council for Educational Research, Hawthorn.

[33] Entwistle, N.J. (1981) Styles of Learning and Teaching: An Integrated Outline of Educational Psychology for Students, Teachers and Lecturers. Wiley, Chichester.

[34] Ramsden, P. (2003) Learning to Teach in Higher Education. RoutledgeFalmer, London.

[35] Marton, F. and Saljo, R. (1976) On Qualitative Differences in Learning I: Outcomes and Process. British Journal of Educational Psychology, 46, 4-11.

https://doi.org/10.1111/j.2044-8279.1976.tb02980.x 